\title{
Phthaloyl amino acids as anti-inflammatory and immunomodulatory prototypes
}

\author{
Ana Cristina Lima Leite - Fábio Fernandes Barbosa - Marcos Veríssimo de Oliveira Cardoso • \\ Diogo R. M. Moreira • Lucas Cunha D. Coêlho • Elany Barbosa da Silva • \\ Gevanio Bezerra de Oliveira Filho • Valdênia Maria Oliveira de Souza • \\ Valéria Rêgo A. Pereira • Luiza de C. Reis • Paulo Michel Pinheiro Ferreira • \\ Claudia Pessoa • Almir Gonçalves Wanderley • Fernanda Virgínia B. Mota • \\ Teresinha G. da Silva
}

Received: 7 May 2013/Accepted: 15 August 2013/Published online: 12 September 2013

(C) Springer Science+Business Media New York 2013

\begin{abstract}
A series of phthalimide analogs were synthesized by derivatization of phthalic anhydride, a highly toxic substance, using a "one pot" condensation reaction to $\alpha$-amino acids. All phthaloyl amino acid derivatives presented anti-oral inflammatory activity, but compounds $\mathbf{2 e}$ and $\mathbf{2 g}$ were found to possess the best activities comparable to thalidomide. Most of the compounds effectively suppressed nitric oxide production in murine cells stimulated with lipopolysaccharide. $\mathrm{N}$ phthaloyl amino acids did not exhibit any significant cytotoxicity in vitro when tested against tumor cells as well as a spleen cell culture of BALB/c mice. Compounds $2 \mathbf{2 a}, \mathbf{2 g}$, and $2 \mathbf{h}$ were able to inhibit TNF- $\alpha$ and IL- $1 \beta$ production by macrophages. At the same concentration, thalidomide did not exhibit significant inhibitory activity.
\end{abstract}

Keywords $N$-phthaloyl amino acids .

Anti-inflammatory $\cdot$ Immunomodulatory

A. C. L. Leite $(\bowtie) \cdot$ F. F. Barbosa - M. V. O. Cardoso

D. R. M. Moreira - L. C. D. Coêlho - E. B. da Silva

G. B. O. Filho - V. M. O. de Souza

Departamento de Ciências Farmacêuticas, Centro de Ciências da

Saúde, Universidade Federal de Pernambuco, Recife,

PE 50740-520, Brazil

e-mail: acllb2003@yahoo.com.br

V. R. A. Pereira $\cdot$ L. de C. Reis

Departamento de Imunologia, Centro de Pesquisas Ageu

Magalhães-FIOCRUZ, Recife, PE, Brazil

P. M. P. Ferreira

Departamento de Ciências Biológicas, Universidade Federal do

Piauí, Picos, Piauí 64607-670, Brazil

\section{Introduction}

It is well known that the free radicals formed during inflammation play an important role in killing the microorganism and activating leukocytes and macrophages. Overproduction of these radicals is associated with a wide range of pathological conditions (Ariel and Serhan, 2007; Nathan, 2002). Thus, it is important to develop antiinflammatory and immunomodulatory drugs that could regulate the overproduction of these undesirable species (Moormann et al., 2001).

Phthalimides are well-known plant growth regulators (Butula et al., 1975; Hoffmann and Smith, 1949; Koch, 1971), bacteriostatic agents (Kant and Saksena, 2003; Midtvedt, 1963), and fungicides (Kennedy et al., 1975). Thalidomide, a multi-target drug, is the best-known phthalimide and is a hypnotic/sedative drug with teratogenic effects. Despite these effects, thalidomide has never completely vanished as a therapeutic substance. It was found to have a powerful anti-inflammatory effect due to its ability to inhibit the production of the cytokine tumor necrosis factor alpha (TNF- $\alpha$ ), a potent stimulator of inflammation, cellular

\section{Pessoa \\ Departamento de Fisiologia e Farmacologia, Centro de Ciências da Saúde, Universidade Federal do Ceará, Fortaleza, \\ CE 60430-270, Brazil}

\section{A. G. Wanderley}

Departamento de Fisiologia e Farmacologia, Centro de Ciências da Saúde, Universidade Federal de Pernambuco, Recife, PE 50740-520, Brazil

\section{F. V. B. Mota - T. G. da Silva}

Departamento de Antibióticos, Universidade Federal de Pernambuco, Recife, PE 50740-520, Brazil 
necrosis, and tissue damage in general (Fernández-Martínez et al., 2001). The anticancer activity of thalidomide is based on the inhibition of the growth of new vessels in the process of angiogenesis (Lepper et al., 2004). Thalidomide is being increasingly used in the clinical management of a wide spectrum of immunologically mediated infectious diseases and cancers such as erythema nodosum leprosum, multiple myeloma, renal and intestinal carcinomas, Behçet's, Crohn's, and a number of dermatologic diseases, as well as rheumatoid arthritis and wasting syndrome in AIDS (Franks et al., 2004; Gockel et al., 2004; Kerr and Ship, 2003; Lu et al., 2003; Sayarlioglu et al., 2004; Srinivasan and Lichtenstein, 2004; Zhu et al., 2003). It is also effective for mycobacterial infection in the central nervous system, for example, tuberculous meningitis caused by Mycobacterium bovis or Mycobacterium bacillus (Tsenova et al., 1999).

Based on the broad spectra of thalidomide properties, the phthalimide pharmacophore has been the target of research with varying intentions. The method by which phthalimide reduces TNF- $\alpha$ production is associated with the induction of the degradation of TNF- $\alpha$ m-RNA (Kim et al., 2004; Lentzsch et al., 2002; Orzeszko et al., 2003; Yogeeswari et al., 2003). $N$-substituted phthalimides are of high interest because they have been reported to possess hypolipidemic activity (Srivastava et al., 2001) as well as anti-inflammatory and immunomodulatory properties (Hashimoto, 2002; Lima et al., 2002; Sena et al., 2003). Phthalimides also have a number of applications in synthetic chemistry (Casimir et al., 2000; Kukolja and Lammert, 1975). In fact, a number of reports have described the synthesis of $N$-phthaloyl amino acids fusing free amino acids with phthalic anhydride (Billman and Harting, 1948; Zeng et al., 2004). To the best of our knowledge, no biological activity tests have been performed for this structural core; therefore, we were interested in carrying out the pharmacological evaluations of these small compounds. This communication reports the results of the in vivo anti-inflammatory tests and immunomodulatory profile. In addition, the compounds were evaluated for their cytotoxicity against human tumor cell lines and a spleen cell culture from BALB/c mice.

\section{Results and discussion}

Chemistry

The compounds were synthesized according to described procedures by fusing free amino acids with phthalic anhydride (Fig. 1) (Zeng et al., 2004). It is worth mentioning that only the desired $S$-enantiomers were obtained in all cases, as verified by the addition of the chiral shift reagent $\mathrm{Eu}(\mathrm{hfc})_{3}$ in the ${ }^{1} \mathrm{H}-\mathrm{NMR}$ spectra.
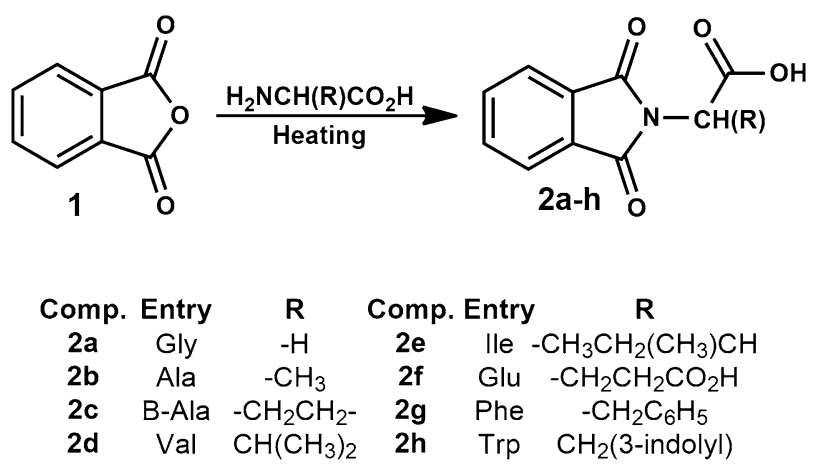

Fig. 1 General synthesis of $N$-phthaloyl amino acid derivatives

Biological activities

Compounds 2a-g were screened for anti-inflammatory activity in an air pouches model assay with a single dose of $100 \mathrm{mg} / \mathrm{kg}$ orally administered to mice and evaluated for their ability to inhibit leukocyte migration from the blood circulation into air pouches (Table 1).

To determine the selectivity and immunomodulatory action, the effect of the derivatives on the proliferation of spleen cells from BALB/c mice (a method that is effective for the evaluation of specific $\mathrm{T}$ lymphocyte cytotoxicity) and their effects on NO-induced production in murine spleen cells were tested using thalidomide (Thl) as a reference.

Compounds 2a and $\mathbf{2 b}$ showed a weak anti-inflammatory profile, whereas $\mathbf{2 c}, \mathbf{2 d}$, and $\mathbf{2 h}$ presented moderate activity. The derivatives $\mathbf{2 e}, \mathbf{2 f}$, and $\mathbf{2 g}$ (an isoleucine, glutamic acid, and phenylalanine derivative, respectively) were the most potent anti-inflammatory agents. It is

Table 1 Anti-inflammatory activity orally of phthalimides $\mathbf{2 a - h}$ and thalidomide (Thl)

\begin{tabular}{lll}
\hline Treated $(100 \mathrm{mg} / \mathrm{kg})$ & No. of PMNL/mL $\left(\times 10^{6}\right)$ & Inhibition $\%$ \\
\hline Vehicle & $5.4 \pm 0.1^{*}$ & - \\
2a & $2.8 \pm 0.2^{*}$ & 47.7 \\
$\mathbf{2 b}$ & $3.3 \pm 0.2^{*}$ & 38.4 \\
$\mathbf{2 c}$ & $2.5 \pm 0.1^{*}$ & 54.2 \\
$\mathbf{2 d}$ & $2.3 \pm 0.3^{*}$ & 57.8 \\
$\mathbf{2 e}$ & $1.8 \pm 0.2^{*}$ & 67.5 \\
$\mathbf{2 f}$ & $2.1 \pm 0.4$ & 61.7 \\
$\mathbf{2 g}$ & $1.9 \pm 0.1^{*}$ & 64.2 \\
$\mathbf{2 h}$ & $3.0 \pm 0.2^{*}$ & 43.8 \\
Thl & $1.5 \pm 0.2^{*}$ & 72.1 \\
\hline
\end{tabular}

The data represent the mean \pm the standard error of 6 animals $P M N L$ polymorphonuclear leukocytes

$* P<0.05$. Significance was determined with one way ANOVA followed by Bonferroni's post hoc test when compared with control group 
interesting to note that the amino acid derivative $2 \mathbf{f}$ (a synthetic precursor of Thl) presented a $15 \%$ decrease in anti-inflammatory activity relative to Thl.

Previous work has shown that the inflammatory effects of carrageenan in the air pouch are due to an influx of predominantly neutrophilic leukocytes (mainly PMNL) from the blood circulation, and the reduction in PMNL suggests the inhibition of prostaglandin (PG) production (Jacobs et al., 1981). Therefore, the air pouch model is an attractive method for the direct measurement of PG, TNF$\alpha$, and NO, among other inflammatory mediators.

The data shown in Table 2 provide evidence that these phthalimides are efficient at reducing lipopolysaccharide (LPS)-induced nitric oxide production at non-cytotoxic levels and at stimulating the proliferation of spleen cells without affecting cell viability at the dose assayed. These results indicate that these compounds are promising antiinflammatory agents, especially compounds $\mathbf{2 e}$ and $\mathbf{2 g}$. Compound $\mathbf{2 b}$ (an alanine derivative) did not provide significant anti-inflammatory activity, but it was able to reduce the production of NO at non-cytotoxic levels.

To better understand the inhibitory effects on NO for the amino acid $\mathbf{2 h}$, the in vivo biological aspects were investigated using the air pouches model and the NO content of the fluid was measured by the Griess reaction. In the fluid samples from the air pouch, $\mathbf{2 h}$ and Thl (at a dose of $10 \mathrm{mg} / \mathrm{kg}$ ) significantly decreased the concentration of LPS-induced nitric oxide production compared to the control group (Table 2).

Thereafter, compounds $\mathbf{2 e}$ and $\mathbf{2 h}$ were selected to test the dose-dependent response of the anti-inflammatory activity. When compound $\mathbf{2} \mathbf{e}$ was given at an oral dose of

Table 2 Inhibitory effects on LPS-induced nitric oxide production and cytotoxic effect on spleen cell BALB/c mice

\begin{tabular}{llllll}
\hline Treated + LPS $^{\mathrm{a}}$ & \multicolumn{2}{l}{ NO-levels $(\mu \mathrm{g} / \mathrm{mL}) \pm \mathrm{SD}^{*}$} & & \multicolumn{2}{l}{ Cytotoxic effects } \\
\cline { 2 - 3 } \cline { 5 - 6 } & at $25 \mu \mathrm{g} / \mathrm{mL}$ & at $50 \mu \mathrm{g} / \mathrm{mL}$ & & Conc. $(\mu \mathrm{g} / \mathrm{mL})^{\mathrm{b}}$ & $\%$ Inhibition $^{\mathrm{c}}$ \\
\hline Thl & $3.6 \pm 0.0^{*}$ & $3.6 \pm 0.0^{*}$ & & $>100$ & None \\
$\mathbf{2 a}$ & $4.2 \pm 0.9$ & $3.6 \pm 2.3$ & 50 & 25.60 \\
$\mathbf{2 b}$ & $2.1 \pm 0.3^{*}$ & $1.5 \pm 0.6^{*}$ & $>100$ & None \\
$\mathbf{2 c}$ & $3.6 \pm 0.0^{*}$ & $4.4 \pm 1.2$ & 50 & 22.20 \\
$\mathbf{2 d}$ & $6.4 \pm 0.0$ & $2.7 \pm 0.6^{*}$ & 25 & 24.69 \\
$\mathbf{2 e}$ & $3.1 \pm 0.0^{*}$ & $2.3 \pm 0.0^{*}$ & 12.5 & 26.06 \\
$\mathbf{2 f}$ & $2.9 \pm 0.9^{*}$ & $3.4 \pm 0.3^{*}$ & 50 & 08.75 \\
$\mathbf{2 g}$ & $2.3 \pm 0.0^{*}$ & $0.7 \pm 0.0^{*}$ & 25 & 21.52 \\
$\mathbf{2 h}$ & $1.3 \pm 0.9^{*}$ & $2.1 \pm 1.4^{*}$ & 50 & 27.62
\end{tabular}

NO-induced production by stimulating with lipopolysaccharide (LPS-1.0 $\mu \mathrm{g} /$ $\mathrm{mL}$ ) and measured by Griess's method [36]

$* P<0.05$ compared with control (only LPS stimulus)

${ }^{a}$ NO-induced levels induced by LPS $7.5 \pm 1.2 \mu \mathrm{g} / \mathrm{mL}$

b The highest nontoxic concentration on spleen cell of BALB/c mice

c $\%$ of viable cells
$10 \mathrm{mg} / \mathrm{kg}$, it displayed a $64.7 \%$ inhibition of inflammation, which is comparable to thalidomide (76.3\% inhibition). Compound $\mathbf{2 h}$ (a tryptophyl derivative), which presented poor anti-inflammatory activity orally, was very potent in inhibiting the production of NO, and it did not show cytotoxicity for mammalian cells at a high dose (50 $\mu \mathrm{g} / \mathrm{mL}$ ) (Fig. 2).

Furthermore, the compounds were evaluated in vitro against a 4-cell-line panel consisting of MDA/MB-435 (human breast), HCT-8 (human colon carcinoma), and SF295 (human glioblastoma) using a previously described MTT assay (Mosmann, 1983). In this protocol, each cell line is inoculated and preincubated on a microtiter plate. Test agents were then added at a single concentration (25 $\mu \mathrm{g} / \mathrm{mL})$, and the culture was incubated for $48 \mathrm{~h}$. Endpoint determinations are made with MTT. The results for each test agent were reported as the percent of growth of the treated cells compared to the untreated control cells. Compounds that reduce the growth of any one of the cell lines to $32 \%$ or less are considered cytotoxic (de Moreira et al., 2007). According to these criteria, the derivatives were considered non-cytotoxic (Table 3).

To evaluate the levels of TNF- $\alpha$ and IL-1 $\beta$, human macrophages were incubated with $50 \mu \mathrm{mol}$ of compounds $\mathbf{2 a}-\mathbf{h}$ over a 24-h time course. These cells were then stimulated with LPS. The purpose of this test was to evaluate the biological capacity of the molecules found to inhibit the synthesis of these extremely important cytokines in inflammatory processes and cancers. The data presented in Fig. 3a show that compounds $\mathbf{2} \mathbf{a}$ and $\mathbf{2 h}$ both inhibit the secretion of TNF- $\alpha$ by macrophages at $50 \mu \mathrm{mol} / \mathrm{mL}$. In addition, as shown in Fig. 3b, compounds $\mathbf{2 a}, \mathbf{2 g}$, and $\mathbf{2 h}$ inhibit IL-1 $\beta$ production at the same concentration

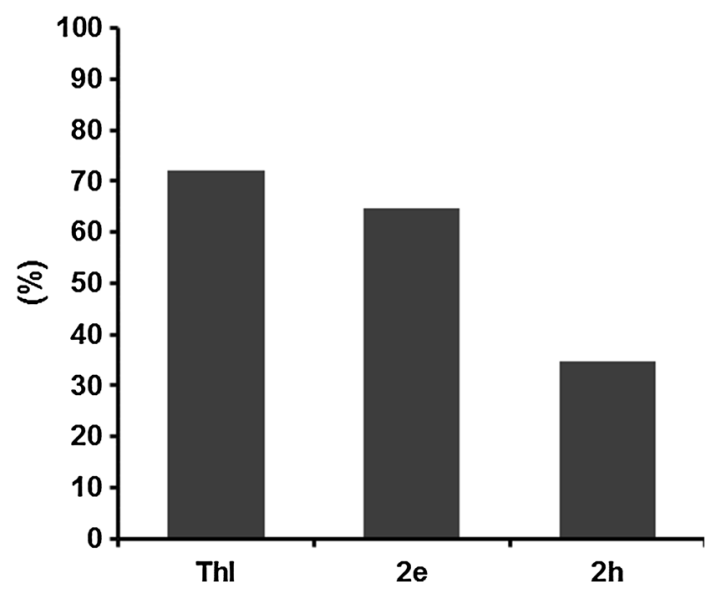

Fig. 2 Anti-inflammatory effects of the compounds $\mathbf{2 e}, \mathbf{2 h}$, and Thl. The results are expressed as the percentage of inhibition for $n=6$ animals. The percent of inhibition was obtained by comparison with a vehicle control group (data not shown) after $6 \mathrm{~h}$ (p.o.) of treatment 
Table 3 Antiproliferative activity against human cancer cells

\begin{tabular}{lccc}
\hline Treated & \multicolumn{3}{c}{ Inhibition of cell proliferation $(\% \pm \mathrm{SD})$ at $25 \mu \mathrm{g} / \mathrm{mL}^{\mathrm{a}}$} \\
\cline { 2 - 4 } & MDA/MB-435 & HCT-8 & SF-295 \\
\hline $\mathbf{2 a}$ & $-4.72 \pm 0.25$ & $-0.61 \pm 2.30$ & $3.98 \pm 15.39$ \\
$\mathbf{2 b}$ & $5.01 \pm 22.38$ & $6.11 \pm 2.88$ & $12.21 \pm 4.26$ \\
$\mathbf{2 c}$ & $-3.71 \pm 0.29$ & $18.94 \pm 12.53$ & $12.57 \pm 7.01$ \\
$\mathbf{2 d}$ & $7.82 \pm 2.87$ & $4.28 \pm 1.87$ & $2.74 \pm 5.88$ \\
$\mathbf{2 e}$ & $14.95 \pm 1.32$ & $15.02 \pm 3.67$ & $20.00 \pm 6.01$ \\
$\mathbf{2 f}$ & $12.92 \pm 5.96$ & $6.52 \pm 2.88$ & $14.42 \pm 7.63$ \\
$\mathbf{2 g}$ & $11.72 \pm 1.03$ & $-7.23 \pm 2.30$ & $13.54 \pm 5.38$ \\
$\mathbf{2 h}$ & $13.75 \pm 2.43$ & $10.44 \pm 3.67$ & $24.51 \pm 8.39$ \\
Dox & $94.64 \pm 0.93$ & $97.07 \pm 4.15$ & $81.36 \pm 0.80$ \\
\hline
\end{tabular}

${ }^{a}$ Standard deviation is given in parentheses

$(50 \mu \mathrm{mol} / \mathrm{mL})$. Thalidomide did not provide significant inhibitory activity.

Compound 2a (a phthaloyl-glycine derivative) had presented weak anti-inflammatory activity, but it exhibited an immunomodulatory profile when tested for NO, TNF- $\alpha$, and IL-1 $\beta$ production. Compound $\mathbf{2 g}$ (a phthaloyl-phenylalanine derivative) showed oral anti-inflammatory activity in the air pouch model, and its immunomodulatory profile showed moderate activity for NO production and strong inhibitory activity for IL-1 $\beta$ production. The phthaloyltryptophyl derivative, $\mathbf{2 h}$, exhibited immunomodulatory activity toward NO, TNF- $\alpha$, and IL- $1 \beta$ production but poor anti-inflammatory activity with oral administration.


Fig. 3 a Effect of the amino acyl phthalimides and Thl in on the production of TNF- $\alpha$ in mouse macrophages $\left(2 \times 10^{6}\right.$ cells $\left./ \mathrm{mL}\right)$ stimulated with LPS $(2 \mu \mathrm{g} / \mathrm{mL})$. TNF- $\alpha$ was measured after $24 \mathrm{~h}$ of incubation with compounds $(50 \mu \mathrm{M})$ by sandwich ELISA (eBioscience kit). Data are the mean \pm S.D obtained in triplicate. b Effect of phthalimides and Thl on the production of interleukin- $1 \beta$ (IL-1 $\beta$ ) in mouse macrophages $\left(2 \times 10^{6}\right)$ stimulated with LPS $\left(2 \mu \mathrm{g} / \mathrm{mL}^{-1}\right)$. IL-1 $\beta$ was measured after $24 \mathrm{~h}$ of incubation with compounds $(50 \mu \mathrm{M})$ by sandwich ELISA (eBioscience kit). Data are the mean $\pm \mathrm{SD}$ (standard deviation) obtained in triplicate. Thl, thalidomide

\section{Conclusion}

In summary, $N$-phthaloyl amino acids were readily synthesized and evaluated for their anti-inflammatory activity and cytotoxicity, as well as their NO, TNF- $\alpha$, and IL-1 $\beta$ production inhibition. These amino acids possess simple structures and could be easily structurally improved. In this series, derivatives from the amino acids, isoleucine and phenylalanine, showed the best oral anti-inflammatory activity in an air pouch model. Moreover, the stimulation of lymphocyte proliferation and the inhibition of NO production suggest that the compounds could be considered as potential immunomodulatory agents. The tryptophyl derivative presented the best immunomodulatory activity of the series. Investigation of immunomodulation and toxicological profiles are subjects for further studies.

\section{Experimental}

\section{General}

Melting points were determined on an electrothermal capillary melting point apparatus and were uncorrected. ${ }^{1} \mathrm{H}$ and ${ }^{13} \mathrm{C}$ NMR spectra were recorded on a Varian Unit Plus instrument (300 MHz for protons and $75.5 \mathrm{MHz}$ for carbon). All chemical shifts are reported in ppm relative to TMS as an internal standard. IR spectra were recorded with a Brucker model IFS66 FT-IR spectrophotometer using $\mathrm{KBr}$ pellets. All chemicals were purchased from Aldrich, Vetec, or Fluka and were used without additional purification.

\section{Chemistry}

All reagents were used as purchased from commercial sources (Sigma-Aldrich, Acros Organics, Vetec, or Fluka). The progress of the reactions was monitored by thin-layer chromatography (TLC) analysis (Merck, silica gel 60 F254 in aluminum foil). The chemical identity was confirmed by NMR and IR spectroscopy and accurate mass (HRMS). IR was performed in $\mathrm{KBr}$ pellets. For NMR spectroscopy, we used either a Varian UnityPlus $300 \mathrm{MHz} 1 \mathrm{H}(300 \mathrm{MHz})$ and $13 \mathrm{C}(75.5 \mathrm{MHz})$ or a Bruker AMX-300 MHz $1 \mathrm{H}$ $(300 \mathrm{MHz})$ and $13 \mathrm{C}(75.5 \mathrm{MHz})$ instrument. DMSO- $d 6$ and $\mathrm{D}_{2} \mathrm{O}$ were purchased from CIL or Sigma-Aldrich. Chemical shifts are reported in ppm, and multiplicities are given as $\mathrm{s}$ (singlet), $\mathrm{d}$ (doublet), $\mathrm{t}$ (triplet), $\mathrm{q}$ (quartet), and $\mathrm{m}$ (multiplet). NH signals were localized in each spectrum after the addition of a few drops of $\mathrm{D}_{2} \mathrm{O}$. Mass spectrometry experiments were performed on an LC-IT-TOF (Shimadzu). Unless otherwise specified, ESI was carried out in the positive ion mode. Typical conditions were as follows: capillary voltage of $3 \mathrm{kV}$, cone voltage of $30 \mathrm{~V}$, 
and a peak scan between 50 and $1,000 \mathrm{~m} / \mathrm{z}$. The compounds were previously synthesized by Zeng et al. (Zeng et al., 2004).

\section{Synthesis}

A mixture of $0.5 \mathrm{~g}(3.38 \mathrm{mmol})$ of phthalic anhydride 1 and the respective L-amino acid $(3.38 \mathrm{mmol})$ in TEA or 4-DMAP $(0.5 \mathrm{~mL})$ and DMF (three drops) was heated by microwave irradiation for $2 \mathrm{~min}$. The crude mixture was then washed with $n$-hexane $(30 \mathrm{~mL})$, filtered through a Buchner funnel and recrystallized with $0.1 \mathrm{M} \mathrm{KHSO}_{4}$ aq. or chloroform $(40 \mathrm{~mL})$, and dried over anhydrous $\mathrm{Na}_{2} \mathrm{SO}_{4}$. The compounds $\mathbf{2 f}$ and $\mathbf{2 h}$ were obtained by heating at 180 ${ }^{\circ} \mathrm{C}$ in an oil bath for $10 \mathrm{~min}$.

(S)- $N$-Phthaloylglycine (2a) yield: $96 \%$. M.p. $\left({ }^{\circ} \mathrm{C}\right): 187-191 . \mathrm{Rf}: 0.5$ (8:2-chloroform/methanol). ${ }^{1} \mathrm{H}-\mathrm{NMR}$ (300 MHz, ppm): $\delta 4.15$ (s, 2H, $\left.\mathrm{CH}_{2}\right) ; 7.50-7.70(\mathrm{~m}, 4 \mathrm{H}$, $\mathrm{Ar}) ; 10.58\left(\mathrm{~s}, 1 \mathrm{H}, \mathrm{CO}_{2} \mathrm{H}\right) \cdot{ }^{13} \mathrm{C}-\mathrm{NMR}(75.5 \mathrm{MHz}, \mathrm{ppm}): \delta$ $39.1\left(\mathrm{CH}_{2}\right) ; 122.4(\mathrm{C} 2$ and $\mathrm{C} 5) ; 132.6(\mathrm{C} 1$ and $\mathrm{C} 6) ; 135.8$ $(\mathrm{C} 3$ and $\mathrm{C} 4) ; 165.9(\mathrm{C}=\mathrm{O}) ; 174.9\left(\mathrm{CO}_{2} \mathrm{H}\right)$. IR $(\mathrm{KBr}$, $\left.\mathrm{cm}^{-1}\right): 3212(\mathrm{vOH}) ; 1775(\mathrm{vC}=\mathrm{O}) ; 1715(\mathrm{vC}=\mathrm{O}) ; 1401$ (vC-N-C); 1374 (vC-N-C).

(S)-N-Phthaloylalanine (2b) yield: $70 \%$. M.p. $\left({ }^{\circ} \mathrm{C}\right): 135$. Rf:0.46 (8:2-chloroform:methanol). ${ }^{1} \mathrm{H}-\mathrm{NMR}$ (300 MHz, ppm): $\delta 1.70\left(\mathrm{~d}, J=7.5 \mathrm{~Hz}, 3 \mathrm{H}, \mathrm{CH}_{3}\right) ; 5.02(\mathrm{q}$, $J=7.5 \mathrm{~Hz}, 1 \mathrm{H}, \mathrm{CH}) ; 7.70-7.85(\mathrm{~m}, 4 \mathrm{H}, \mathrm{Ar}) ; 10.02(\mathrm{~s}, 1 \mathrm{H}$, $\left.\mathrm{CO}_{2} \mathrm{H}\right) .{ }^{13} \mathrm{C}-\mathrm{NMR}(75.5 \mathrm{MHz}, \mathrm{ppm}): \delta 16.9\left(\mathrm{CH}_{3}\right) ; 51.7$ $(\mathrm{CH} \alpha) ; 122.4(\mathrm{C} 2$ and $\mathrm{C} 5) ; 132.7(\mathrm{C} 1$ and $\mathrm{C} 6) ; 135.8(\mathrm{C} 3$ and $\mathrm{C} 4) ; 165.6(\mathrm{C}=\mathrm{O}) ; 171.9\left(\mathrm{CO}_{2} \mathrm{H}\right) . \mathrm{IR}(\mathrm{KBr}$, $\left.\mathrm{cm}^{-1}\right): 3205(\mathrm{vOH}) ; 1752(\mathrm{vC}=\mathrm{O}) ; 1740(\mathrm{vC}=\mathrm{O}) ; 1469$ (vC-N-C); 1397 (vC-N-C).

(S)- $\mathrm{N}$-Phthaloylbetaalanine (2c) yield: $90 \%$. M. p. $\left({ }^{\circ} \mathrm{C}\right)$ :133-135. Rf:0.5(8:2-chloroform:methanol). ${ }^{1} \mathrm{H}-\mathrm{NMR}$ (300 MHz, ppm): $\delta 2.50\left(\mathrm{t}, J=15.0 \mathrm{~Hz}, 2 \mathrm{H}, \mathrm{CH}_{2}\right) ; 3.77(\mathrm{t}$, $\left.J=15.0 \mathrm{~Hz}, 2 \mathrm{H}, \mathrm{CH}_{2}\right), 7.67-7.51(\mathrm{~m}, 4 \mathrm{H}, \mathrm{Ar}), 8.07$ (s, $\left.1 \mathrm{H}, \mathrm{CO}_{2} \mathrm{H}\right) .{ }^{13} \mathrm{C}-\mathrm{NMR}(75.5 \mathrm{MHz}, \mathrm{ppm}): \delta 29.5\left(\mathrm{CH}_{2}\right)$; $33.1(\mathrm{CH} \alpha) ; 122.4(\mathrm{C} 2$ and $\mathrm{C} 5) ; 132.6(\mathrm{C} 1$ and $\mathrm{C} 6) ; 135.8$ $(\mathrm{C} 3$ and $\mathrm{C} 4) ; 165.9(\mathrm{C}=\mathrm{O}) ; 175.9\left(\mathrm{CO}_{2} \mathrm{H}\right) . \mathrm{IR}(\mathrm{KBr}$, $\left.\mathrm{cm}^{-1}\right): 3170(\mathrm{vOH}) ; 1771(\mathrm{vC}=\mathrm{O}) ; 1727(\mathrm{vC}=\mathrm{O}) ; 1466$ $(\mathrm{vC}-\mathrm{N}-\mathrm{C}) ; 1411(\mathrm{vC}-\mathrm{N}-\mathrm{C})$.

(S)- $\mathrm{N}$-Phthaloylvaline (2d) yield: $50 \%$. M.p. $\left({ }^{\circ} \mathrm{C}\right)$ :79-81. Rf:0.60 (8:2-chloroform:methanol). ${ }^{1} \mathrm{H}-\mathrm{NMR}$ $(300 \mathrm{MHz}, \quad \mathrm{ppm}): \delta \quad 1.9 \quad\left(\mathrm{~d}, \quad J=4.0 \mathrm{~Hz}, \quad 6 \mathrm{H}, \quad \mathrm{CH}_{3}\right)$; 2.70-2.79 (m, 1H, CH); $4.98(\mathrm{~d}, J=5.0 \mathrm{~Hz}, 1 \mathrm{H}, \mathrm{CH} \alpha)$; $8.11(\mathrm{~d}, J=7 \mathrm{~Hz}, \mathrm{Ar}) ; 8.16(\mathrm{~d}, J=7.0 \mathrm{~Hz}, \mathrm{Ar}) ; 9.14(\mathrm{~s}$, $1 \mathrm{H}, \mathrm{OH}) .{ }^{13} \mathrm{C}-\mathrm{NMR}(75.5 \mathrm{MHz}, \mathrm{ppm}): \delta 18.9\left(\mathrm{CH}_{3}\right) ; 29.5$ $(\mathrm{CH}) ; 56.5(\mathrm{CH} \alpha) ; 122.4(\mathrm{C} 2$ and $\mathrm{C} 5) ; 130.7(\mathrm{C} 1$ and $\mathrm{C} 6)$; $135.9(\mathrm{C} 3$ and $\mathrm{C} 4) ; 165.5(\mathrm{C}=\mathrm{O}) ; 172.9\left(\mathrm{CO}_{2} \mathrm{H}\right)$. IR $\left(\mathrm{KBr}, \quad \mathrm{cm}^{-1}\right): 3234 \quad\left(\mathrm{vCO}_{2} \mathrm{H}\right) ; 1763 \quad(\mathrm{vC}=\mathrm{O}) ; 1691$ $(\mathrm{vC}=\mathrm{O}) ; 1469(\mathrm{vC}-\mathrm{N}-\mathrm{C}) ; 1401(\mathrm{vC}-\mathrm{N}-\mathrm{C})$.

(S)- $\mathrm{N}$-Phthaloylisoleusine (2e) yield: $74 \%$. M.p. $\left({ }^{\circ} \mathrm{C}\right): 110-112 . \mathrm{Rf}: 0.5$ (8:2-chloroform:methanol). ${ }^{1} \mathrm{H}-\mathrm{NMR}$
(300 MHz, ppm): $\delta 0.87(\mathrm{~d}, J=7.2 \mathrm{~Hz}, 3 \mathrm{H}) ; 1.22(\mathrm{t}$, $J=6.3 \mathrm{~Hz}, 3 \mathrm{H}) ; 1.50-1.49(\mathrm{~m}, 2 \mathrm{H}) ; 2.54-2.52(\mathrm{~m}, 1 \mathrm{H})$; $4.70(\mathrm{~d}, J=8.4 \mathrm{~Hz}, 1 \mathrm{H}) ; 7.87-7.72(\mathrm{~m}, 4 \mathrm{H}) ; 9.45(\mathrm{~s}, 1 \mathrm{H}$, $\mathrm{OH}) .{ }^{13} \mathrm{C}-\mathrm{NMR}(75.5 \mathrm{MHz}, \mathrm{ppm}): \delta 10.6\left(\mathrm{CH}_{3}\right) ; 16.6$ $\left(\mathrm{CH}_{3}\right) ; 25.4\left(\mathrm{CH}_{2}\right) ; 33.9(\mathrm{CH}) ; 56.5(\mathrm{CH} \alpha) ; 122.9(\mathrm{C} 4$ and C9); 131.3 (C5 and $\mathrm{C} 8$ ); 133.8 (C6 and $\mathrm{C} 7$ ); 167.5 $(\mathrm{C}=\mathrm{O}) ; 170.3\left(\mathrm{CO}_{2} \mathrm{H}\right)$. IR $\left(\mathrm{KBr}, \mathrm{cm}^{-1}\right): 3250(\mathrm{vOH})$; $1763(\mathrm{vC}=\mathrm{O}) ; 1703(\mathrm{vC}=\mathrm{O}) ; 1460(\mathrm{vC}-\mathrm{N}-\mathrm{C}) ; 1394$ (vC-N-C).

(S)- $N$-Phthaloylglutamine (2f) yield $=31.9 \%$. M.p. $\left({ }^{\circ} \mathrm{C}\right): 204-209 . R f=0.58$ (8:2-chloroform:methanol). ${ }^{1} \mathrm{H}-$ NMR $(300 \mathrm{MHz}, \quad \mathrm{ppm}): \delta \quad 2.48-2.63\left(\mathrm{~m}, 1 \mathrm{H}, \mathrm{CH}_{2}\right)$; 2.11-2.05 (m, 1H, $\left.\mathrm{CH}_{2}\right) ; 2.96-2.84\left(\mathrm{~m}, 2 \mathrm{H}, \mathrm{CH}_{2}\right)$; 5.13-5.19 (m, 1H, CH $\alpha)$; 7.87-7.90 (m, 4H, Ar); $7.80(\mathrm{~m}$, $4 \mathrm{H}, \mathrm{Ar}) ; 11.15\left(\mathrm{~s}, 1 \mathrm{H}, \mathrm{CO}_{2} \mathrm{H}\right) ; 11.33\left(\mathrm{~s}, 1 \mathrm{H}, \mathrm{CO}_{2} \mathrm{H}\right)$; The 11.15 and 11.33 signals disappear after adding $\mathrm{D}_{2} \mathrm{O} .{ }^{13} \mathrm{C}$ NMR (75.5 MHz, ppm): $\delta 22.044\left(\mathrm{CH}_{2}\right) ; 30.995\left(\mathrm{CH}_{2}\right)$; $49.025(\mathrm{CH} \alpha) ; 122.967$ (C2 and $\mathrm{C} 5) ; 131.261$ (C1 and $\mathrm{C} 6)$; $134.927(\mathrm{C} 3$ and $\mathrm{C} 4) ; 167.217(\mathrm{C}=\mathrm{O}) ; 169.960\left(\mathrm{CO}_{2} \mathrm{H}\right)$; $172.873\left(\mathrm{CO}_{2} \mathrm{H}\right)$. IR $\left(\mathrm{KBr}, \mathrm{cm}^{-1}\right): 3201(\mathrm{vOH}) ; 1775$ $(\mathrm{vC}=\mathrm{O}) ; 1740(\mathrm{vC}=\mathrm{O}) ; 1465(\mathrm{vC}-\mathrm{N}-\mathrm{C})$.

(S)- $\mathrm{N}$-Phthaloylphenylalanine $(\mathbf{2} \mathbf{g})$ yield $=87.4 \%$. M.p. $\left({ }^{\circ} \mathrm{C}\right): 167-170 . \quad \mathrm{R} f: 0.54$ (8:2-chloroform:methanol). ${ }^{1} \mathrm{H}-\mathrm{NMR}(300 \mathrm{MHz}, \mathrm{ppm}): \delta 3.60(\mathrm{~d}, J=9.0 \mathrm{~Hz}, 2 \mathrm{H}$, $\left.\mathrm{CH}_{2}\right) ; 5.258(\mathrm{t}, J=7.0 \mathrm{~Hz}, 1 \mathrm{H}, \mathrm{CH} \alpha) ; 7.15-7.196(\mathrm{~m}, 5 \mathrm{H}$, Ar); 7.65-7.68 (m, 2H, Ar); 7.76-7.790 (m, 2H, Ar); 9.01 (s, $1 \mathrm{H}, \mathrm{OH}) .{ }^{13} \mathrm{C}-\mathrm{NMR}(75.5 \mathrm{MHz}, \mathrm{ppm}): \delta 34.0\left(\mathrm{CH}_{2}\right)$; $52.9(\mathrm{CH} \alpha) ; 123.4\left(\mathrm{C}^{\prime}\right.$ and $\left.\mathrm{C}^{\prime}\right) ; 126.6$ (C5 and $\left.\mathrm{C} 9\right) ; 128.3$ (C6); 128.7 (C8); $130.7\left(\mathrm{C}^{\prime}\right)$; $135.0\left(\mathrm{C}^{\prime}\right.$ and $\left.\mathrm{C}^{\prime}\right)$; 137.3 (C4); $167.2(\mathrm{C}=\mathrm{O}) ; 170.2\left(\mathrm{CO}_{2} \mathrm{H}\right)$. IR $\left(\mathrm{KBr}, \mathrm{cm}^{-1}\right): 3274$ $\left(\mathrm{vCO}_{2} \mathrm{H}\right) ; 1752(\mathrm{vC}=\mathrm{O}) ; 1704(\mathrm{vC}=\mathrm{O}) ; 1450(\mathrm{vC}-\mathrm{N}-\mathrm{C})$; 1398 (vC-N-C).

(S)- $\mathrm{N}$-Phthaloyltryptophan $(\mathbf{2}$ h) yield $=96 \%$. M.p. $\left({ }^{\circ} \mathrm{C}\right): 94-96 . \quad \mathrm{R} f=0.48 \quad$ (8:2-chloroform:methanol). ${ }^{1} \mathrm{H}-$ NMR (300 MHz, ppm): $\delta 3.58\left(\mathrm{~d}, J=7.00 \mathrm{~Hz}, 2 \mathrm{H}, \mathrm{CH}_{2}\right)$; $5.15(\mathrm{t}, J=7.00 \mathrm{~Hz}, 1 \mathrm{H}, \mathrm{CH} \alpha) ; 6.89(\mathrm{t}, J=8.00 \mathrm{~Hz}, 4 \mathrm{H}$, Ar); 7.03 (m, 4H, Ar); 7.27 (d, $J=9.00 \mathrm{~Hz}, 4 \mathrm{H}, \mathrm{Ar}) ; 7.49$ (d, $J=9.00 \mathrm{~Hz}, 4 \mathrm{H}, \mathrm{Ar}) ; 7.79$ (s, 4H, Ar); 10.762 (s, 1H, $\mathrm{NH})$; The 10.762 signal disappear after adding $\mathrm{D}_{2} \mathrm{O} .{ }^{13} \mathrm{C}$ NMR (75.5 MHz, ppm): $\delta 24.140\left(\mathrm{CH}_{2}\right) ; 52.680(\mathrm{CH} \alpha)$; 109.758 (C7); 111.517 (C4); 117.960 (C10); 118.475 (C9); 121.049 (C8); $123.399\left(\mathrm{C} 2^{\prime}\right.$ and $\left.\mathrm{C}^{\prime}\right) ; 126.964$ (C11); $130.920\left(\mathrm{C}^{\prime}\right.$ and $\left.\mathrm{C} 6^{\prime}\right) ; 134.923\left(\mathrm{C}^{\prime}\right.$ and $\left.\mathrm{C} 4^{\prime}\right) ; 168.545$ $(\mathrm{C}=\mathrm{O}) ; 170.461\left(\mathrm{CO}_{2} \mathrm{H}\right)$. IR $\left(\mathrm{KBr}, \mathrm{cm}^{-1}\right): 3406(v \mathrm{NH})$; $3258(v \mathrm{OH}) ; 1771(\mathrm{vC}=\mathrm{O}) ; 1715(\mathrm{vC}=\mathrm{O}) ; 1464(\mathrm{vC}-$ $\mathrm{N}-\mathrm{C})$.

Biological evaluation

Culture of normal, tumor cells, and cytotoxicity assays

Heparinized human blood (from healthy, nonsmoker donors who had not taken any drugs for at least 15 days 
prior to sampling, aged between 18 and 35 years old) was collected, and peripheral blood mononuclear cells (PBMCs) were isolated by a standard method of density gradient centrifugation over Ficoll-Hypaque. All studies were performed in accordance with Brazilian research guidelines (Law 196/96, National Council of Health) and with the Declaration of Helsinki.

\section{Culture of colon (HCT-8)}

Glioblastoma (SF-295) and melanoma (MDA/MB-435) cancer lines and PBMC were grown in RPMI 1640 medium supplemented with $20 \%$ fetal bovine serum, $2 \mathrm{mM}$ glutamine, $100 \mathrm{U} / \mathrm{mL}$ penicillin, and $100 \mu \mathrm{g} / \mathrm{mL}$ streptomycin at $37{ }^{\circ} \mathrm{C}$ with $5 \% \mathrm{CO}_{2}$. The cytotoxicity of the compounds against human cancer cells was determined by the MTT assay (Mosmann, 1983), which analyzes the ability of living cells to reduce the yellow dye 3-(4,5-dimethyl-2thiazolyl)-2,5-diphenyl-2H-tetrazolium bromide (MTT) to a purple formazan product. Briefly, cells were plated in 96-well plates $\left(0.3-0.7 \times 10^{5}\right.$ cells/well) and incubated to allow cell adhesion. Twenty-four hours later, extracts were added to each well $(0.04-100 \mu \mathrm{g} / \mathrm{mL})$. After $72 \mathrm{~h}$ of incubation, the supernatant was replaced by fresh medium containing $10 \%$ MTT, the formazan product was dissolved in DMSO, and the absorbance was measured at $595 \mathrm{~nm}$. Quantification of cell proliferation was determined spectrophotometrically using a multiplate reader (DTX 880 Multimode Detector, Beckman Coulter). Control groups (negative and positive) received the same amount of DMSO (0.1\%). Doxorubicin (Dox) $(0.02-8.6 \mu \mathrm{M})$ was used as a positive control.

\section{Preparation of splenocytes}

Mouse splenocytes were obtained by Pereira et al. (Hernandes et al., 2010). After killing the animal with $\mathrm{CO}_{2}$ gas, the spleen of each mouse was removed aseptically and placed in a Falcon tube containing RPMI 1640 with fetal calf serum (complete medium). In a vertical flow, each spleen was transferred to a Petri dish where they were soaked. The cell suspensions obtained were transferred to Falcon tubes containing approximately $10 \mathrm{~mL}$ of incomplete medium by spleen. Spleen homogenates were overlaid onto a Ficoll-Paque ${ }^{\mathrm{TM}}$ PLUS layer with the density adjusted to $1.076 \mathrm{~g} / \mathrm{mL}$ and centrifuged at $1,000 \times g$ at room temperature for $25 \mathrm{~min}$. The interface cell layer containing immune cells was recovered by a Pasteur pipette, washed twice in PBS, and centrifuged two times at $500 \times g$ for $10 \mathrm{~min}$. Cells were counted in a Neubauer chamber, and cell viability was determined by the trypan blue exclusion method. Cells were used only when viability was greater than $98 \%$.
In vitro cytotoxicity assays

The cytotoxicity of compounds $\mathbf{2} \mathbf{a}-\mathbf{h}$ was determined using $\mathrm{BALB} / \mathrm{c}$ mice splenocytes $\left(6 \times 10^{5}\right.$ cells/well $)$ cultured in 96-well plates in RPMI 1640 media (Sigma Chemical Co., St. Louis, MO) supplemented with $10 \%$ fetal bovine serum (FCS; Cultilab, Campinas, SP, Brazil) and $50 \mu \mathrm{g} /$ $\mathrm{mL}$ of gentamycin (Novafarma, Anápolis, GO, Brazil). Each compound was evaluated at six concentrations (100, $50,25,10,5$, and $1 \mu \mathrm{g} / \mathrm{mL}$ ) in triplicate in two independent assays. Cultures were incubated in the presence of $\left[{ }^{3} \mathrm{H}\right]$ thymidine (Amersham Biosciences) $(1 \mu \mathrm{Ci} /$ well) for $24 \mathrm{~h}$ at $37{ }^{\circ} \mathrm{C}$ and $5 \% \mathrm{CO}_{2}$. After this period, the content of the plate was harvested to determine the $\left[{ }^{3} \mathrm{H}\right]$-thymidine $\left(\left[{ }^{3} \mathrm{H}\right] \mathrm{TdR}\right)$ incorporation using a beta-radiation counter $(\beta$ matrix 9600, Packard). The toxicity of compounds $\mathbf{2 a}-\mathbf{h}$ was determined by comparing the percentage of $\left[{ }^{3} \mathrm{H}\right]$-thymidine incorporation (as an indicator of cell viability) of lectin-treated wells compared to untreated wells. Saponine $(0.05 \%)$, concanavalin A (Con A), and phytohemagglutinin (PHA) were used as positive controls. Non-cytotoxic concentrations were defined as those causing a reduction in $\left[{ }^{3} \mathrm{H}\right]$-thymidine incorporation below $30 \%$ in relation to untreated controls.

\section{Carrageenan-induced air pouch}

The anti-inflammatory activity of the compounds was tested by the formation of air pouches on the dorsal cervical region of mice $(25-30 \mathrm{~g})$ by subcutaneous injection of $2.5 \mathrm{~mL}$ of sterile air on day 0 followed by a second injection of $2.5 \mathrm{~mL}$ of sterile air 3 days later. On the 6th day, the mice received vehicle or the test compounds orally. One hour after drug administration, inflammation was induced by injecting $1 \mathrm{~mL}$ of carrageenan suspension ( $1 \%$ in saline solution) into the air pouch. After $6 \mathrm{~h}$, the mice were killed and the lumen of the air pouch was lavaged by intrapouch injection of $3 \mathrm{~mL}$ of PBS containing $50 \mathrm{ng} / \mathrm{mL}$ heparin and subsequent aspiration of the fluid. Total numbers of PMNL cell infiltration were determined with a Neubauer hemocytometer.

\section{In vitro nitrite analysis}

The mice spleen cells were used to evaluate the concentration of nitrite after treatment with LPS and the compounds $2 \mathbf{a}-\mathbf{h}$ (at 25 and $50 \mu \mathrm{g} / \mathrm{mL}$ ), and after $72 \mathrm{~h}$ of incubation, the media were carefully collected for measurement by the colorimetric Griess method (Ding et al., 1988). The NO concentration was estimated by a standard curve of sodium nitrite $(3.12-50 \mu \mathrm{mol} / \mathrm{mL})$. 
$T N F-\alpha$ and IL-1 $\beta$ levels

Mice peritoneal macrophages were placed into 96-well plates at a cell density of $2 \times 10^{6}$ cells $/ \mathrm{mL}$ and incubated for $2 \mathrm{~h}$ at $37{ }^{\circ} \mathrm{C}$ and $5 \% \mathrm{CO}_{2}$. Cells at a concentration of $2 \times 10^{6}$ were suspended in RPMI 1640 with $5 \%$ FBS, 100 $\mathrm{UI} / \mathrm{mL}$ of penicillin, $100 \mu \mathrm{g} / \mathrm{mL}$ of streptomycin, and $50 \mathrm{mM}$ 2-mercaptoethanol. One hundred microliters of the suspension and $100 \mu \mathrm{L}$ of the samples were incubated with $2 \mu \mathrm{g} / \mathrm{mL}$ LPS (positive control) or with the test compounds in different concentrations. After $24 \mathrm{~h}$, the supernatants were removed and kept at $-80{ }^{\circ} \mathrm{C}$ until the evaluation of cytokine levels (TNF- $\alpha$ and IL-1 $)$. The doses of cytokines in the exudates were assayed by sandwich ELISA using monoclonal antibodies specific to the detection of the cytokine.

Acknowledgments We would like to thank the Brazilian National Research Council (CNPq), FACEPE, and FIOCRUZ for financial support. MVOC received a CNPq doctoral scholarship and currently receives a FACEPE researcher scholarship. We also thank the Department of Fundamental Chemistry-UFPE for recording the ${ }^{1} \mathrm{H}-$ NMR and IR spectra of all compounds.

Conflict of interest The authors state no conflict of interest.

\section{References}

Ariel A, Serhan CN (2007) Resolvins and protectins in the termination program of acute inflammation. Trends Immunol 28:176-183. doi:10.1016/j.it.2007.02.007

Billman JH, Harting WF (1948) Amino acids; phthalyl derivatives. J Am Chem Soc 70:1473. doi:10.1021/ja01184a051

Butula LJ, Kujundzić N, Malnar M, Vukusić I (1975) Mitodepressive effect of some $N$-substituted phthalimides on Lepidium sativum. Die Pharm 30:754

Casimir JR, Didierjean C, Aubry A et al (2000) Stereoselective alkylation of $N$-boc-protected-5-substituted $\delta$-lactams: synthesis of $\alpha, \delta$-disubstituted $\delta$-amino acids. Org Lett 2:895-897. doi:10. 1021/o19913136

de Moreira DRM, Lima Leite AC, Pinheiro Ferreira PM et al (2007) Synthesis and antitumour evaluation of peptidyl-like derivatives containing the 1,3-benzodioxole system. Eur J Med Chem 42:351-357. doi:10.1016/j.ejmech.2006.10.007

Ding A, Nathan C, Stuehr D (1988) Release of reactive nitrogen intermediates and reactive oxygen intermediates from mouse peritoneal macrophages. Comparison of activating cytokines and evidence. J Immunol 141:2407-2412

Fernández-Martínez E, Morales-Ríos MS, Pérez-Álvarez V, Muriel P (2001) Effects of thalidomide and 3-phthalimido-3-(3,4-dimethoxyphenyl)-propanamide on bile duct obstruction-induced cirrhosis in the rat. Drug Dev Res 54:209-218. doi:10.1002/ ddr. 10022

Franks ME, Macpherson GR, Figg WD (2004) Thalidomide. Lancet 363:1802-1811. doi:10.1016/S0140-6736(04)16308-3

Gockel HR, Lügering A, Heidemann J, et al. (2004) Thalidomide induces apoptosis in human monocytes by using a cytochrome c-dependent pathway. J Immunol (Baltimore Md: 1950) 172:5103-9

Hashimoto Y (2002) Structural development of biological response modifiers based on thalidomide. Bioorg Med Chem 10:461-479
Hernandes MZ, Rabello MM, Leite ACL et al (2010) Studies toward the structural optimization of novel thiazolylhydrazone-based potent antitrypanosomal agents. Bioorg Med Chem 18:7826-7835. doi:10.1016/j.bmc.2010.09.056

Hoffmann OL, Smith AE (1949) A new group of plant growth regulators. Science (New York, NY) 109:588. doi: 10.1126/ science.109.2841.588

Jacobs RS, White S, Wilson L (1981) Selective compounds derived from marine organisms: effects on cell division in fertilized sea urchin eggs. Fed Proc 40:26-29

Kant P, Saksena RK (2003) Synthesis and antimicrobial activity of some new 2-phenyl-3-p-(2'-methyl-3'-aryl-4'-oxo-thiazolin-2' yl) phenyl quinazolin-4-ones and 2-phenyl-3-p-( $1^{\prime}$-aryl-3-phthalimido-4' -methylazetidin-2'-one-2' -yl) phenyl-quinazolin-4ones. Indian J Heterocycl Chem 12:315-318

Kennedy GL, Arnold DW, Keplinger ML (1975) Mutagenicity studies with captan, captofol, folpet and thalidomide. Food and cosmetics toxicology 13:55-61

Kerr AR, Ship JA (2003) Management strategies for HIV-associated aphthous stomatitis. Am J Clin Dermatol 4:669-680. doi:10. 2165/00128071-200304100-00002

Kim YS, Kim JS, Jung HC, Song IS (2004) The effects of thalidomide on the stimulation of NF-kappaB activity and TNF-alpha production by lipopolysaccharide in a human colonic epithelial cell line. Mol Cells 17:210-216

Koch H (1971) Phytopharmakologische Untersuchung von Thalidomid, seinen Metaboliten and einigen strukturverwandten Verbindungen. Sci Pharm 39:209-247

Kukolja S, Lammert SR (1975) Azetidinone antibiotics. XIV. Removal of a phthaloyl protective group from acid and base sensitive compounds. J Am Chem Soc 97:5582-5583. doi:10. 1021/ja00852a044

Lentzsch S, Rogers MS, LeBlanc R et al (2002) S-3-Aminophthalimido-glutarimide inhibits angiogenesis and growth of B-cell neoplasias in mice. Cancer Res 62:2300-2305

Lepper ER, Ng SSW, Gütschow M et al (2004) Comparative molecular field analysis and comparative molecular similarity indices analysis of thalidomide analogues as angiogenesis inhibitors. J Med Chem 47:2219-2227. doi:10.1021/jm0304820

Lima LM, Castro P, Machado AL et al (2002) Synthesis and antiinflammatory activity of phthalimide derivatives, designed as new thalidomide analogues. Bioorg Med Chem 10:3067-3073

Lu KQ, Brenneman S, Burns R et al (2003) Thalidomide inhibits UVB-induced mouse keratinocyte apoptosis by both TNF-alphadependent and TNF-alpha-independent pathways. Photodermatol Photoimmunol Photomed 19:272-280

Midtvedt T (1963) The effect of thalidomide on the growth curve of a riboflavin dependent microbe. Acta Pathol Microbiol Scandinavica 58:355-362

Moormann AE, Metz S, Toth MV et al (2001) Selective heterocyclic amidine inhibitors of human inducible nitric oxide synthase. Bioorg Med Chem Lett 11:2651-2653

Mosmann T (1983) Rapid colorimetric assay for cellular growth and survival: application to proliferation and cytotoxicity assays. J Immunol Methods 65:55-63

Nathan C (2002) Points of control in inflammation. Nature 420:846-852. doi:10.1038/nature01320

Orzeszko A, Vilpo J, Vilpo L, Kamińska B (2003) Synthesis and anticancer activity of $5^{\prime}$-phthaloylnucleosides. Pharmazie 58: $169-172$

Sayarlioglu M, Kotan MC, Topcu N et al (2004) Treatment of recurrent perforating intestinal ulcers with thalidomide in Behçet's disease. Ann Pharmacother 38:808-811. doi:10.1345/aph.1D524

Sena VLM, Srivastava RM, Silva RO, Lima VLM (2003) Synthesis and hypolipidemic activity of $N$-substituted phthalimides. Part V. Farmaco (Società chimica italiana: 1989) 58:1283-8 
Srinivasan R, Lichtenstein GR (2004) Recent developments in the pharmacological treatment of Crohn's disease. Expert Opin Investig Drugs 13:373-391. doi:10.1517/13543784.13.4. 373

Srivastava RM, Oliveira FJ, Da Silva LP et al (2001) Synthesis and hypolipidemic activity of $\mathrm{N}$-phthalimidomethyl tetra- $O$-acylalpha- $D$-mannopyranosides. Carbohydr Res 332:335-340

Tsenova L, Bergtold A, Freedman VH et al (1999) Tumor necrosis factor alpha is a determinant of pathogenesis and disease progression in mycobacterial infection in the central nervous system. Proc Natl Acad Sci USA 96:5657-5662
Yogeeswari P, Sriram D, Saraswat V et al (2003) Synthesis and anticonvulsant and neurotoxicity evaluation of N4-phthalimido phenyl (thio) semicarbazides. Eur J Pharmaceut Sci Off J Eur Fed Pharmaceut Sci 20:341-346

Zeng Q, Liu Z, Li B, Wang F (2004) Mild and effective $N$ phthaloylation of amino acids. Amino Acids 27:183-186. doi:10. 1007/s00726-004-0109-1

Zhu X, Giordano T, Yu Q-S et al (2003) Thiothalidomides: novel isosteric analogues of thalidomide with enhanced TNF-alpha inhibitory activity. J Med Chem 46:5222-5229. doi:10.1021/ jm030152f 